\title{
The Impact of Aspect Ratio on External Heat Gain of Multi-storey Office Buildings in Jakarta
}

\author{
Wasiska Iyati ${ }^{1}$, Eryani Nurma Yulita ${ }^{2}$, Jusuf Thojib ${ }^{3}$, Heru Sufianto ${ }^{4}$ \\ 1,23,4 Department of Architecture, Engineering Faculty \\ Universitas Brawijaya \\ wasiska.iyati@gmail.com
}

\begin{abstract}
The narrow land in big cities such as Jakarta, increases the amount of high rise building, especially multi-storey office building. Office building consumes much energy to provide air conditioning to meet the thermal comfort inside the building. On the other hand, the building shape, building envelope, and building orientation to the sun's position are the main factors in building design aspects that affect the amount of cooling load. This study aims to investigate the impact of the aspect ratio or the ratio of the longer dimension of an oblong plan to the shorter, on external heat gain of multi-storey office building. Variables examined include the transparent and solid area of building envelope, the total area of the surface of the building envelope in any orientation, and the volume of the building, as well as the influence of those proportion on the external heat gain. This study uses mathematical calculations to predict the cooling load of the building, particularly external heat gain through the walls, roof and glass, as well as comparative analysis of models studied. The study also aims to generate the design criteria of building form and proportion of multi-storey office buildings envelope with lower external heat gain. In Jakarta climatic conditions, the result on rectangular building plan with aspect ratio of 1 to 4 shows that the external heat gain did not differ significantly, and the smallest heat gain is found on the aspect ratio of 1.8. Results also showed that the greater aspect ratio, the greater reduction of external heat gain obtained by changing the orientation of the longest side facing east-west into the northsouth, about $2.79 \%$ up to $42.14 \%$ on the aspect ratio of 1.1 to 4 . In addition, it is known that in same building volume, changing the number of floors from 10 to 50 can improve the external heat gain almost twice.
\end{abstract}

Keywords: aspect ratio, surface-to-volume-ratio, building external heat gain, multistorey office building

\section{Background}

The development in economy and the limitation of land led to increased vertical buildings growth in major cities in Indonesia. In big cities such as Jakarta, this is occuring in buildings with the function as rental office, due to high price of land accompanied by the need of space to support economic activities. On the other hand, high rise buildings have some consequences on the operational stage of the building. One of them is the high energy consumption to comply the air conditioning and artificial lighting in buildings. The building cooling load can be determined by the external heat gain received from solar thermal 
radiation, as well as internal heat gain received from occupation, artificial lighting, and elelctronic equipments.

Heat gain of buildings depend on gains through glass or transparent material on building envelope (sensible heat gain), heat transmission through the wall and roof (transmission gain), internal heat gain consisting of humans sensible and latent heat gain, heat from lighting and electronic equipment, as well as gains from outdoor air or infiltration and mechanical ventilation (Grondzik, Kwok, 2015, SNI 03-6572-2001). Meanwhile, according to Szokolay, 2004, a building can be considered as a thermal system, with a series of heat inputs and outputs. In Timmeren in Knaack and Klein, 2009, climatic factors become one of the main aspects that define the building envelopes design, where the building envelope as a mediator between the outdoor and indoor space of the building.

In Szokolay, 2004, thermal performance of buildings is strongly influenced by shapes, materials, fenestration and ventilation. The building shapes comprising the ratio of the surface area of the building envelope to the building volume (surface-to-volume ratio), as well as the aspect ratio or the division of length and building width (on the rectangular plan) as well as the long-side orientation of the building, generally determined in the early stages of building design. Szokolay mentioned that in order to reduce the external heat gain, in most instances, the north and south walls should be longer than the east and west, with the aspect ratio would be around 1.3 to 2, depending on the conditions of temperature and solar radiation at each location. While in Yeang, 1994, the optimum high-layered floor plan for tropical climates is a rectangular plan with the longest side facing north and south, with the ratio between width and length is $1: 3$.

Nowadays, the building envelope technology has many technological advances and improvements in thermal, visual and energy performance. The use of glass material on the building envelope has increased considerably in efforts to reduce energy consumption for air conditioning in buildings (Timmeren in Knaack and Klein, 2009). While in the office building, external heat gain from solar radiation is not only caused by the envelope's material, but also the shape of the building plan, and its orientation to the sun's position. According to Lechner, 2015, large office buildings with tower plan type can be divided into five zones, based on the solar thermal radiation received. In the tropics, this kind of building will have an eastward orientation that tends to heat in the morning and afternoon, a westward orientation that tends to heat in the afternoon to late afternoon, as well as more shade on the side facing north and south. In Ling, Ahmad, and Ossen, 2007, geometric shape of the building greatly influences the received of solar thermal radiation, such as the building height, the building plan or the basic shape of the building, the shape of the building envelope, the ratio between the width and building length, and also the solar shading strategies. The research showed that the square shape with 1:1 ratio in a northsouth orientation receives the lowest annual total solar insolation compared to other square shapes, and receives the highest amount of solar insolation on the east-orientated wall, followed by the south-, west- and north-orientated walls respectively. According to the research on the effect of shape and orientation of buildings in Ghana by Koranteng and Abaitey, 2010, all the rectangular forms show the least cooling load with the orientation of north or south with the maximum cooling loads for all the orientations was at east and west. According to McKeen and Fung, 2014, understanding the degree to which the aspect ratio effects performance building is useful in building design. 
In Indonesia's tropical areas, multi-storey buildings receive a large exposure of solar radiationon their buildings envelope, it is increasing the building cooling load of buildings. The heat gain derived from solar thermal radiation is influenced by the orientation to the sun's position, that the aspect ratio or the ratio between the width and length of the building (on the rectangular floor plans) used in a particular orientation will affect how much the cooling load of the building. Meanwhile, determining the floor numbers for the building will affect the surface area of building envelope, thus affecting the amount of heat received through window elements, walls, and building roofs. Optimal planning started from the design of building shape, especially the aspect ratio and building orientation, needs to be considered in early stages of design to reduce external heat gain. It is aiming to reduce the energy consumption for building cooling load, particularly in the tropical climate area. Rental office building designs with typical floor design that demand high commercial profits, are also demanding to spend low operational building cost.This can be done by reducing the external heat gain from solar thermal radiation, to reduce the building cooling load. Reduction of external heat gain through the windows, walls, and building roofs, needs to be applied through the design of building shape that includes the proportion of dimensions as well as building orientation. In the other hand, reducing the building cooling load should be done in an effort to minimize the negative impacts of buildings to the environment, along with actualizing a sustainable design. The design criteria for rental office buildings which include aspect ratio and the ratio between the surface area and building volume, particularly for the climate condition in Jakarta. It is expected to be the input for the designers to produce more energy efficent building designs.

\section{Method}

This quantitative research is conducted started from data collection through literature and comparative study. Comparative analysis is further used as a method in determining the performance of the building models researched. Comparison is done by looking at the amount of building cooling load, especially the external heat gain through windows, walls, and building roofs, using mathematical calculations.

\section{$2.1 \quad$ Research Variables}

The variables studied in this research are determined to limit the research by staying focused on the research objectives, with aspect ratio ( 1 until 4), building orientation (the longest side facing east-west and north-south), ratio between surface area and building volume (altitude between 10 until 50 floors) as independent variables, and building's external heat gain as dependent variables.

\subsection{Method of External Heat Gain Calculation}

Referring to the thermal data of Jakarta City and the calculation method of cooling load (Grondzik, Kwok, 2015; Tangoro, 2006) which includes gains through roof and walls, gains through glass, gains from outdoor air, gains from people, gains from lighting, gains from equipment, and latent heat gains, the approximate method for calculating external heat gain in this research is limited to: 
1. Heat gain through the glass or transparent wall, obtain from multiplication of glass area and design cooling load factor for each orientation.

2. Heat gain through the roof and wall, obtain from multiplication of roof or wall area, U-factor, and the design equivalent temperature differences.

\subsection{External Heat Gain on Building Models Data}

In this research, the calculation of cooling load on several numbers of multi-storey office buildings model with rectangular plan in Jakarta climatic condition is done mathematically. In this case, the cooling load is limited to external heat gain which includes the heat gain through the glass or windows, and also the heat gain through the massive walls and building roof area (Tangoro, 2006), with the following data :

1. The design cooling load factor through glass on the north side in Jakarta is 686 $\mathrm{Btu} / \mathrm{h} / \mathrm{m}^{2}$ and $398 \mathrm{Btu} / \mathrm{h} / \mathrm{m}^{2}$ on the south side. Meanwhile, $967 \mathrm{Btu} / \mathrm{h} / \mathrm{m}^{2}$ on the east side, and $1063 \mathrm{Btu} / \mathrm{h} / \mathrm{m}^{2}$ on the west side.

2. U-factor through massive walls is $3.22 \mathrm{Btu} / \mathrm{h} / \mathrm{m}^{2}$.

3. U-factor through building roof area is $11.5 \mathrm{Btu} / \mathrm{h} / \mathrm{m}^{2}$.

Afterwards, the average climatic data with the outdoor temperature of $30^{\circ} \mathrm{C}\left(86^{\circ} \mathrm{F}\right)$ and the assumed indoor temperature of $25^{\circ} \mathrm{C}\left(77^{\circ} \mathrm{F}\right)$ are used for Jakarta climatic data with the design equivalent temperature differences about $9^{\circ} \mathrm{F}$.

For the first variable studied, aspect ratio, it used a number of 31 models consisting of multi-storey office buildings with the altitude of 50 floors, building volume of 216.000 $\mathrm{m}^{3}, 50 \%$ window to wall ratio (WWR), and 3,6 m floor to floor height. The determined aspect ratio is between 1 until 4 with an interval of 0.1 . For the second independent variable, orientation of the longest side of the building facing north-south and east-west, given the lovation of Indonesia, especially Jakarta that is located near the equator facing the building to the east or the west will potentially gaining extensive solar thermal radiation for finding how much external heat gain reduction achieved. Meanwhile on the third variable, the ratio between surface area and building volume, is researched using a number of building floors alternative on the same building volume, i.e. 10, 20, 30, 40, and 50 floors.

\section{Results and Discussion}

\subsection{The Correlation Analysis between Aspect Ratio and External Heat Gain}

Figure 1 shows a graph of the correlation between aspect ratio and building external heat gain on models researched in a climatic condition of Jakarta, with the otientation of the longest side facing north-south. The results show that the smallest external heat gain is found in the model with an aspect ratio of 1.8 or the ratio between the width and the lenght of the building is about 1:2. In the other side, although not significant, the graph also shows a tendency of external heat reduction on aspect ratio of 1 to 1.8 as well as external heat reduction increment on aspect ratio of 1.8 to 4 . The reduction amount of external heat gain through window, wall, and building roof on aspect ratio of 1 to 1.8 is $4.33 \%$. Meanwhile, the increase in the amount of external heat gain on aspect ratio of 1.8 to 4 is $7.33 \%$. These results show that exposing the longest side of the building to the north-south side for tropical climate in Jakarta area will produce almost an equal heat gain in aspect ratio of 1 to 4. 


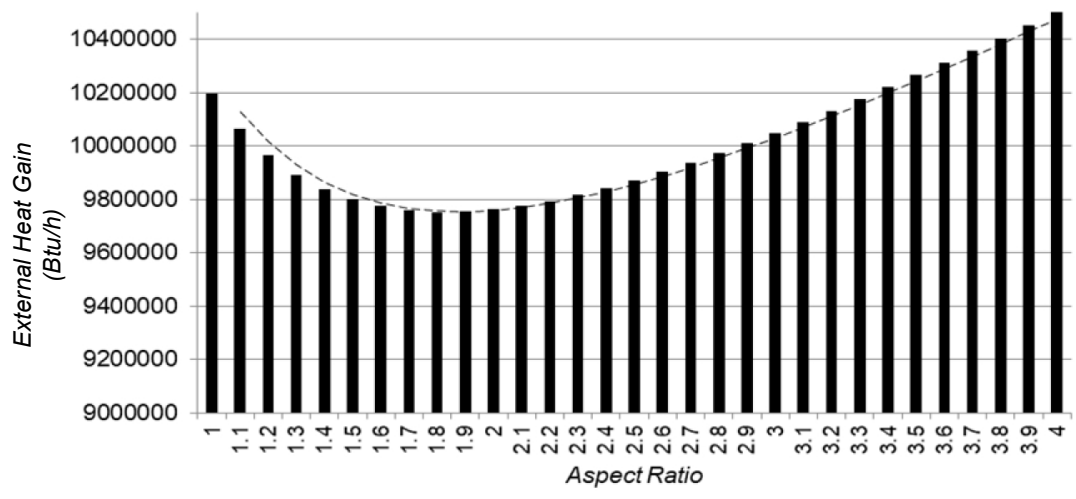

Figure 1. The correlation graph between aspect ratio and building external heat gain.

\subsection{Reduction of Building External Heat Gain on the Model with Longest Side Orientation Facing North-South and East-West}

In the second variable researched, the orientation of the longest side of the building to the sun's position, shows the significant percentage of external heat gain reduction. Facing the longest side of the building to the north-south on tropical climatic condition of Jakarta is able to reduce external heat gain up to $42.14 \%$ on aspect ratio 4 or the ratio between the width and the length of the building of 1:4 (shown on Figure 2). As for the aspect ratio below 2 shows the reduction of external heat gain is below $20 \%$.

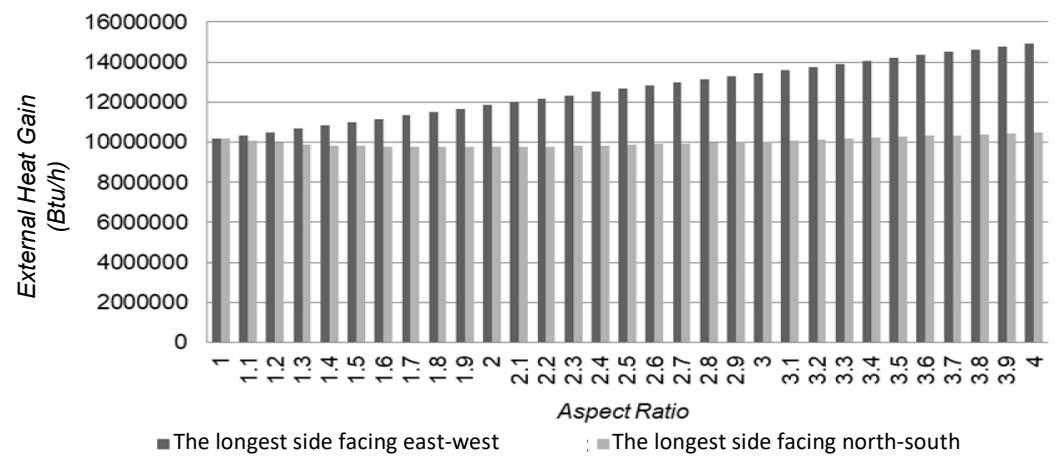

Figure 2. The comparison graph of building external heat gain with the longest side orientation facing the north-south and the east-west.

Although it is not linear, the results also show a tendency that the larger the aspect ratio, the higher the external heat gain reduction achieved. Changing the orientation of the longest side of the building from the east-west to the north-south shows a significant influence in efforts to reduce the energy cinsumption of buildings, started from the design of the building shapes. This is due to the high heat gain through the building envelope facing east and west. Therefore, the determination of building orientation, especially in buildings with rectangular floor plans, is very important to be considered at the planning stage of the building. Meanwhile, if the longest side orientation of the building can not be faced to the north-south direction in tropical climatic area, it is necessary to pay more attention to the type of materials used as building envelope, especially on the east and west sides to reduce the building external heat gain. 


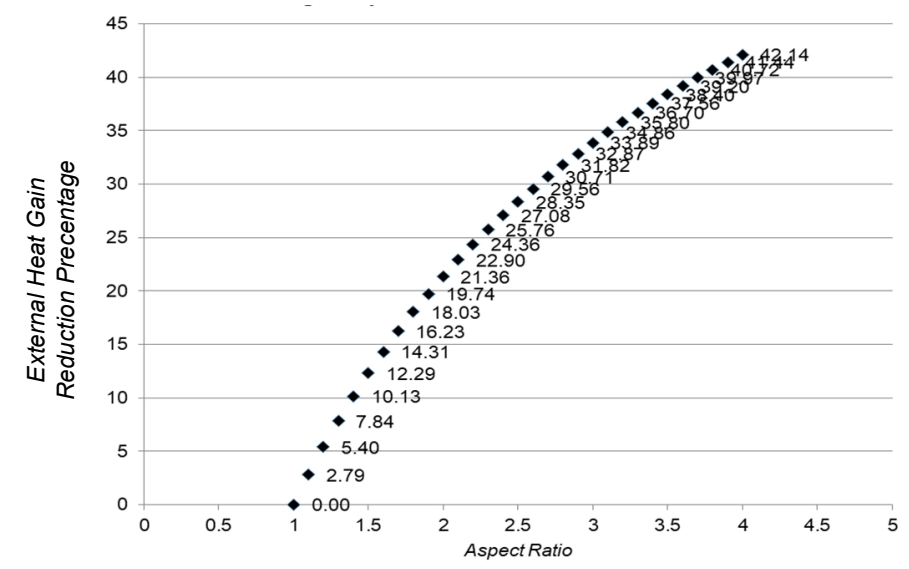

Figure 3. The correlation graph between reduction percentage of external heat gain for the longest side orientation to the east-west and north-south with the building aspect ratio.

\subsection{The Correlation Analysis of the Ratio between Building Surface Area and Building Volume with the Building External Heat Gain}

In the third variable, the influence of building surface area on the building external heat gain is investigated, on the model with the aspect ratio of 1 to 4 and the longest side orientation facing north-south at the same building volume, which amounted about $216,000 \mathrm{~m}^{3}$, researched on office buildings with the amount of floors of $10,20,30,40$, and 50 floors. In this case, the large of typical floor and building envelope area will adjust. The results shown on Figure 4 and Figure 5 that are pointing the correlation graph between the building surface area with the building external heat gain. Where it shows that the more of the amount if building floors, the higher the surface to volume ratio, so the external heat gain will also get higher.

The results show that, on a 50-storey office building model, it can nearly double the external heat gain compared to the 10 -storey office building. The graph shows a significant increase in external heat gain on building models with floors amount of 10, 20, 30, 40 to 50 floors. Figure 5 also shows how large the increase in the ratio of surface to volume by the the building aspect ratio.

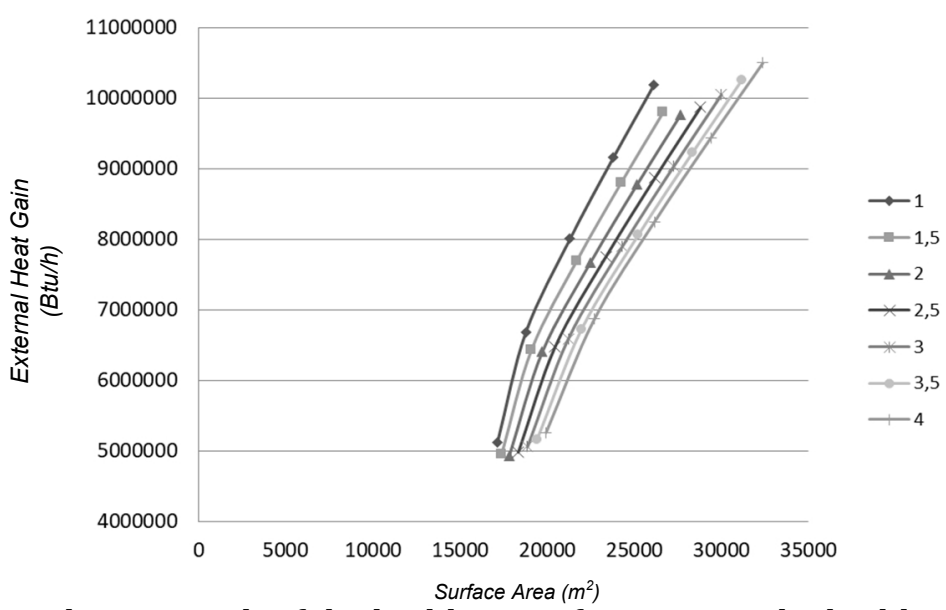

Figure 4. The correlation graph of the building surface area to the building external heat gain. 


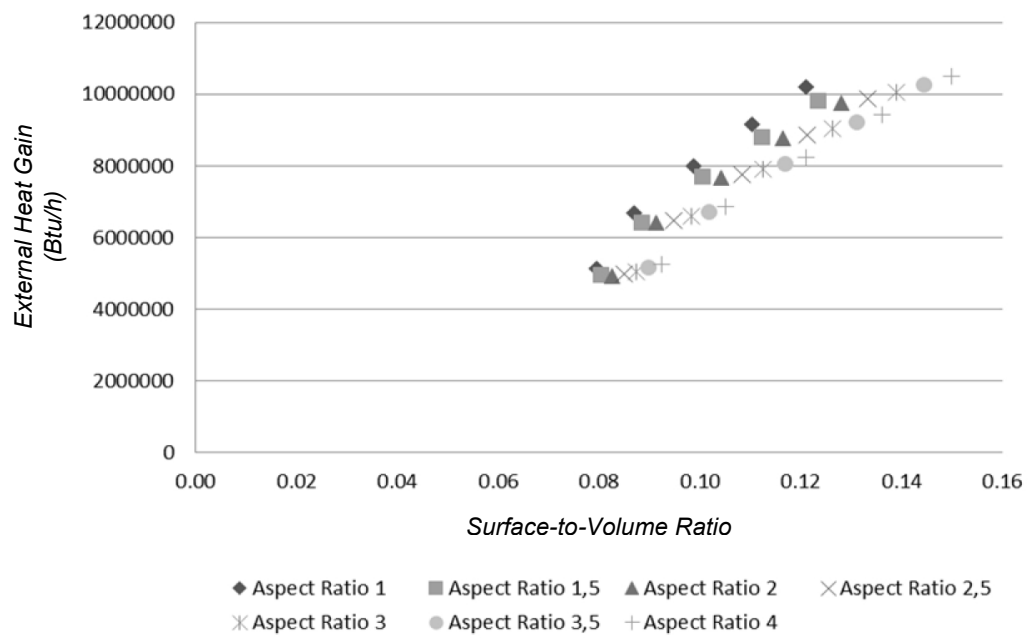

Figure 5. The correlation graph of the surface to volume ratio with the external heat gain.

\section{Conclusion}

Based on the calculation of data analysis that has been done on a number of typical office building models with rectangular plans in climatic condition of Jakarta, the rectangular plan model in Jakarta City with aspect ratio of 1 to 4, shows that the building external heat gain does not differ significantly, with the smallest heat gain found in aspect ratio of 1.8. The results also show that the larger the aspect ratio, the higher the external heat gain reduction achieved by changing the orientatioin of the longest side facing the eastwest to the north-south, which is about $2.79 \%$ to $42.14 \%$ on the aspect ratio of 1.1 to 4 . In addition, it is known that at the same building volume, changing the number of floors from 10 to 50 can increase the external heat load by nearly double.

These results indicate the importance of considering the principles of tropical design in building designs, especially multi-storey buildings where the surface area is larger, so the potential acquisition of solar thermal radiation is also getting bigger. The determination of aspect ratio on buildings with rectangular floor plans, orientation of the longest side of the building to the sun's position, and the determination of number of floors that will affect building surface area, all of them need to be considered starting from the planning stage of the building. Meanwhile, there are some major consequences to consider when these three variables can not be met, such as determining the exact type of building envelope materials, especially on the east and the west sides of the building, as well as lower natural lighting performance on thicker building shapes or less number of building floors.

\section{References}

Badan Standar Nasional Indonesia. 2001. SNI 03-6572-2001 tentang Tata Cara Perancangan Sistem Ventilasi dan Pengkondisian Udara pada Bangunan Gedung.

Grondzik, W.T., Kwok, A.G. 2015. Mechanical and Electrical Equipment for Buildings. New Jersey: John Wiley and Sons, Inc.

Knaack, U., \& Klein, T., (Editors). 2009. The Future Envelope 2: Architecture - Climate - Skin. Amsterdam: IOS Press. 
Koranteng, C., Abaitey, E.G. 2010. The Effects of Form and Orientation on Energy Performance of Residential Buildings in Ghana. Journal of Science and Technology, Vol. 30, No. 1, pp 71-81.

Lechner, N. 2015. Heating, Cooling, Lighting: Design Methods for Architects. New York: John Wiley \& Sons.

Ling, C.S. Ahmad, M.H., Ossen, D.R. 2007. The Effect of Geometric Shape and Building Orientation on Minimising Solar Insolation on Hihg-Rise Buildings in Hot Humid Climate. Journal of Construction in Developing Countries, Vol. 12, No. 1, pp. 27-38.

McKeen, P., Fung, A.S. 2014. The Effect of Building Aspect Ratio on Energy Efficiency: A Case Study for Multi-Unit Residential Buildings in Canada. Buildings, Vol. 4, pp 336-354.

Szokolay, S.V. 2004. Introduction to Architectural Sciences, the Basis of Sustainable Design. Burlington: Architectural Press.

Tangoro, D. 2006. Utilitas Bangunan. Jakarta: UI Press.

Yeang, K. 1994. Bioclimatic Skyscrapers. London, UK: Artemis London Limited. 